\title{
Physiology Professor Alfred Fleisch (1892-1973) and His Legacy at the University of Tartu
}

\section{Leili Kriis}

University of Tartu Museum

Lossi 25,

Tartu 51003, Estonia

E-mail: leili.kriis@ut.ee

"Every researcher carries a grain of sand, only a few ones also have a stone."

(A. Fleisch)

\begin{abstract}
Alfred Fleisch's period as Professor of Physiology and Chemistry at the University of Tartu (1926-1932) was highlighted by outstanding achievements-here he constructed various original devices for studying respiration and blood circulation, published his research results in specialised key magazines together with his Estonian assistant and wrote concise literature reviews for the world's most authoritative manuals. Fleisch's research legacy had an important influence on the directions of post-World War II physiological research at the University of Tartu. World War II shaped the history of continents and the fate of many researchers but did not sever the connection between generations of scholars, as the example of Fleisch's research legacy demonstrates. The University of Tartu Museum's collection includes both a device constructed by Fleisch as well as locally made modifications based on his instruments that were constructed later. Both the objects and archive material found in the museum collection allow us to study the less examined aspects of this topic more thoroughly.
\end{abstract}

Keywords: Alfred Fleisch, device construction, Hugo Masing, physiology, University of Tartu 


\section{Introduction}

Physiologists say that physiology is a fundamental science for understanding "life", how to go about treating diseases and coping with the stresses our bodies are exposed to in different environments. It was not really until the $19^{\text {th }}$ century that physiology started making rapid advancements. The achievements in the field of physiology made by the University of Tartu started at the same time as well. The experimental direction of physiology was founded by Alfred Wilhelm Volkmann (1800-1877, professor in 1837-1842), who began to systematically introduce the methodology used in physiological examinations to the students during his lectures with the help of experiments and microscopy. Friedrich Bidder (1810-1894, professor in 1860-1869) along with the chemist Carl Schmidt (1822-1894) discovered that digestion is a fermentative (enzymatic) process. At the end of the same century, Aleksander Schmidt (1831-1894, professor in 1868-1894) came up with the theory that blood coagulation is a fermentative process.

The greatest figure of the $20^{\text {th }}$ century was Alfred Fleisch from Switzerland, who created the theory of the nutritive regulation of blood circulation during his tenure at the University of Tartu. According to that theory, metabolism products dilate blood vessels in the tissue where they are formed. Therefore, metabolism itself takes care of the necessary blood supply, and, through that, the conditions of tissue nutrition inside the tissues (Fleisch, Sibul \& Ponomarev, 1932; Fleisch \& Sibul, 1933). Another important direction in Fleisch's research was the construction of original equipment and the theoretical substantiation of corresponding methods. Fleisch's research legacy exerted an important influence on post-WW II physiological research directions at the University of Tartu. World War II shaped the history of continents and the fate of many researchers, but did not sever the connection between generations of researchers, as the example of Fleisch's research legacy demonstrates. The academic achievements of Fleisch have been previously discussed by Robert Looga (1921-2015) and Peet-Henn Kingisepp (1936-2012); the candidate and doctoral dissertations based on his legacy have been referenced by Atko-Meeme Viru (1932-2007).

The University of Tartu Museum's collection includes both a device constructed by Fleisch as well as locally made modifications based on his devices that were constructed later. Both the objects and the archive material found in the museum collection allow us to pay more attention to less examined aspects in exploring this topic. 


\section{Professor Alfred Fleisch's successful years at the University of Tartu}

Alfred Fleisch's period as Professor of Physiology and Chemistry at the University of Tartu (1926-1932) was highlighted by outstanding achievements-here he constructed various original devices for studying respiration and blood circulation, published his research results in specialised key magazines together with his Estonian assistant ${ }^{1}$ and wrote concise literature reviews to the world's most authoritative manuals. All this eventually brought recognition not only to the author himself, but to the University of Tartu as well.

Fleisch considered his time here a very important stage of his research history, saying that working in Tartu was no holiday ('kein Otium'), but rather hard work in order to build his future career. This is how he remembered coming to Tartu: "In 1926, Lipschütz (endocrinologist) came to Hess ${ }^{3}$ and myself and announced that he is leaving the cold Tartu for Chile due to his tuberculosis and that I, a Swiss, have great potential to become his successor" (Fleisch, 1972, p. 99).

The University of Tartu of the Republic of Estonia tried to fill vacant seats with local candidates, but there were not enough qualified professors for all specialities. Konstantin Konik (1873-1936), the dean of the Faculty of Medicine, stressed the following in his address to the university's government:

When it comes to physiology and physical chemistry, then this is the most important chair of the faculty, which is very closely tied to not only all the other branches of medicine, but many other faculties as well. Physiology is connected to the Faculty of Mathematics and Natural Science, the subject is obligatory for the students of the Faculty of Veterinary Medicine and the students from the Chairs of Pharmacy and Physical Education of the Faculty of Medicine. Which is why this chair in particular needs someone proficient and of a high status in the field of research. (EAA, 1926-1932, p. 50)

Alfred Fleisch was elected as the Professor of Physiology with the decision made by the Council of the University of Tartu, Faculty of Medicine on 4 November

Professor Fleisch's assistants in Tartu were Leida Adamberg and Viktor Hion in 1927, Maks Tiitso and Leida Adamberg in 1928, Maks Tiitso and Renata Beckmann in 1929-1931, Maks Tiitso, students Ilo Sibul and Vladimir Ponomarev in 1932.

2 Aleksander Lipschütz (1883-1980) was Professor of Physiology of the University of Tartu in 19191926.

3 Walter Rudolf Hess (1881-1973), Professor of Physiology of the University of Zürich 1917-1951, Nobel Prize winner (1949). 
1926 with 19 votes for him and one against, "through election for an unspecified period", to make sure his research here and the thorough preparation of the next generations would be guaranteed (EAA, 1926-1932, p. 51). On 24 November 1926 the decision was approved by G. Nei, on behalf of the Minister of Education, allowing Fleisch to conduct lectures in German (like Professor Lipschütz ${ }^{4}$ ) for five years. Numerous letters of recommendation, including one from Fleisch's Cambridge teacher Frederick Gowland Hopkins (18611947), describing Fleisch as "a highly original thinker and a very able experimentalist" helped

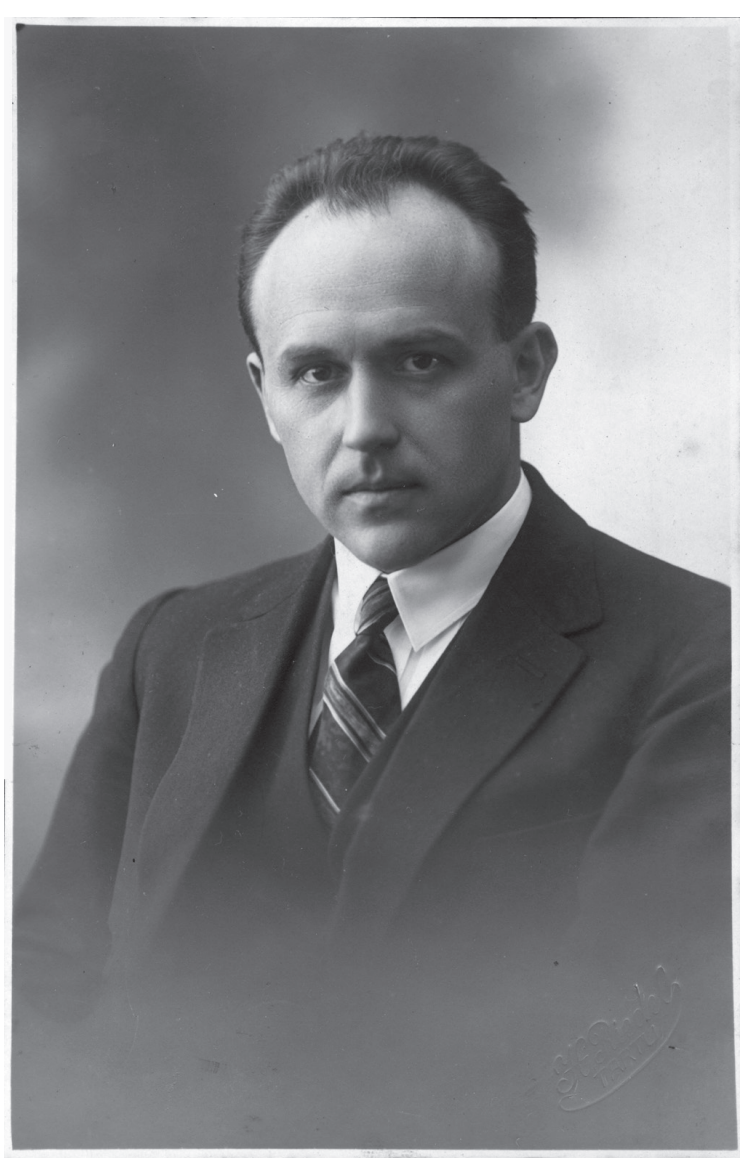

Figure 1. Alfred Fleisch during his time in Tartu.

Photo by H. Riedel.

with getting the position (EAA, 1926-1932, p. 23).

On 25 January 1927, Fleisch held his opening lecture at the assembly hall, and on 10 February 1927 he was sworn into office. In the spring of 1927 he began lectures on physiology and physical chemistry for the students of the Faculty of Medicine and Pharmacy, as well as of the Faculty of Mathematics and Natural Science. After five years, Fleisch asked for permission to continue the lectures in German, which was granted (on 12 October 1931), but after a year he left Tartu, having received an invitation for the position of Professor of Physiology from the University of Lausanne.

4 In the early days of the Estonian university, half of the professors in the Faculty of Medicine spoke German. 
Professor Fleisch tried to create an interest in physiology and the physiological method of research in his students. His lectures contained plenty of information on the research developments of the time, the most important of which he published in the journal Eesti Arst ('Estonian doctor'). Interest in physiology did awake not only among his students but members of other faculties and practical physicians as well. Under the supervision of Alfred Fleisch, the doctoral theses of his co-workers Renata Beckmann (1901-...), Maks Tiitso (1900-1944) and Ilo Sibul (1908-1979), as well as of physicians not working at the Institute of Physiology, Ernst Mill (1896-1987), Valter Steinfeldt (Hiie) (1902-1963) and Franz Grant (1896-1960), were completed.

Alfred Fleisch's academic interests embraced various fields of physiology. He believed that changing one's research topic was simple in his time, as literature concerning different fields was not particularly extensive and it was easy to get accustomed with a topic in a relatively short time. Already as a student at the Department of Physiology of the University of Zürich, Fleisch (owing to the influence of Professor Hess) had grown interested in experimental research on the respiratory and cardiovascular systems-his advancements in the same fields would bring him international recognition during his Tartu period.

The most outstanding of Fleisch's methodical works in Tartu are the construction of the pneumotachometre and the pulse time recorder (also known as the interval recorder) and the theoretical substantiation of the corresponding research methods. He published the working principles of the pneumotachometre and a description of its original construction in 1925 (Fleisch, 1925, pp. 713722), but this method's detailed development, substantiation and application took place in Tartu (Fleisch, 1930, pp. 364-368). Fleisch demonstrated that pneumotachography enables the extremely precise recording of the speed of the air flow in the respiratory tract both in the case of normal and pathological breathing, both in humans and animals. Leslie Silvermann (1914-1966) worked in the same field in the U.S.A. and considered Fleisch the father of pneumotachography (Kingisepp, 2011, pp. 35-36). Fleisch agreed, he wrote: "I constructed the first apparatus and gave it a name. The Metabo factory I established sold more than 900 pneumotachometres in the 1970s and delivered these all over the world." (Fleisch, 1972, pp. 138-139). Pneumotachography has by now developed into one of the main methods of studying external respiration in both specialised laboratories and clinics.

In 1930, Fleisch presented the construction of his new device, the pulse time recorder, to the academia. It was originally designed for the extremely precise 
recording of the intervals between heartbeats (with a precision of $0.0033 \mathrm{sec}$ ) on a kymograph tape in vertical lines (ordinates), which gives it the name of pulse time recorder (Pulszeitschreiber). The pros of the device were its great precision and the brief but compendious nature of the written curve-a few metres of kymograph tape allowed to constantly record the changes in the frequency of heart contractions over several hours, and the transcribed alterations could be clearly observed even with the naked eye. Should the same results be replicated using the widespread ECG method, it would take hundreds of metres of tape, as well as require cumbersome and time-consuming measuring and calculating (Looga, 1975, p. 28).

With the help of pulse time recording, Professor Fleisch and his Tartu assistants, Renata Beckmann and Maks Tiitso, described in detail the changes in the frequencies of heart contractions in various physiological conditions, during psychological stress, etc. Some conclusions:

1) Respiratory sinus arrhythmia and the so-called long waves in the pulse rate frequency are completely physiological phenomena. Rather, if these are absent, it is a sign of pathology, since such a condition can be found in the elderly and cardiac patients;

2) A compendious table of the fluctuations in pulse time during respiratory arrhythmia enabled to measure the size of the dispersion quickly, using simple comparison;

3) Statistical analysis, a novel approach at the time, was widely used;

4) The old forgotten idea of the veins' active participation in the regulation of the peripheral circulation was confirmed. Before that, most authors believed the veins played only a passive role in it (Fleisch, 1930, pp. 390-400).

Continuing work on his idea, Fleisch improved his device and demonstrated that it is well-suited for recording all sorts of periodical processes, such as (1) pulse times, (2) duration of respiratory phases, (3) reaction times, (4) work of ergometers, (5) extrasystoles, (6) frequency of falling droplets. He named the improved device the ordinate recorder (Ordinat-Zeitenschreiber), later an orthochronograph. Fleisch licensed this device to the Braun company in Melsungen (Germany), which continued to produce these machines until 1970 (Fleisch, 1972, p. 141). 
Fleisch actively participated in international researchers' meetings, where he presented the devices and research results developed by him and his colleagues at the University of Tartu, Laboratory of Physiology. During one of his last reports to the Faculty of Medicine, he wrote:

On 22 August 1932 I was in Rome at an international physiologists' congress, where I presented two new devices constructed by me at the University of Tartu Institute of Physiology, namely one new device ${ }^{5}$ and the pulse time recorder (Pulszeitschreiber), which I have already previously presented in Wiesbaden, at a congress of internal medicine (Kongress für innere Medizin). These presentations took place during two afternoons and the working devices were presented to hundreds of physiologists, pharmacologists and internists. (EAA, 1926-1932, p. 135)

After leaving Tartu, Alfred Fleisch worked for 30 years as Professor of Physiology at the University of Lausanne. He undertook numerous scientific activities besides teaching, including the Directorship of the Swiss Institute for Vitamins. He was a member of many international scientific societies and academies and also acted as a consultant for international firms and organisations. He was a doctor honoris causa of the University of Nancy, France (Kingisepp, 2011, pp. 35-36).

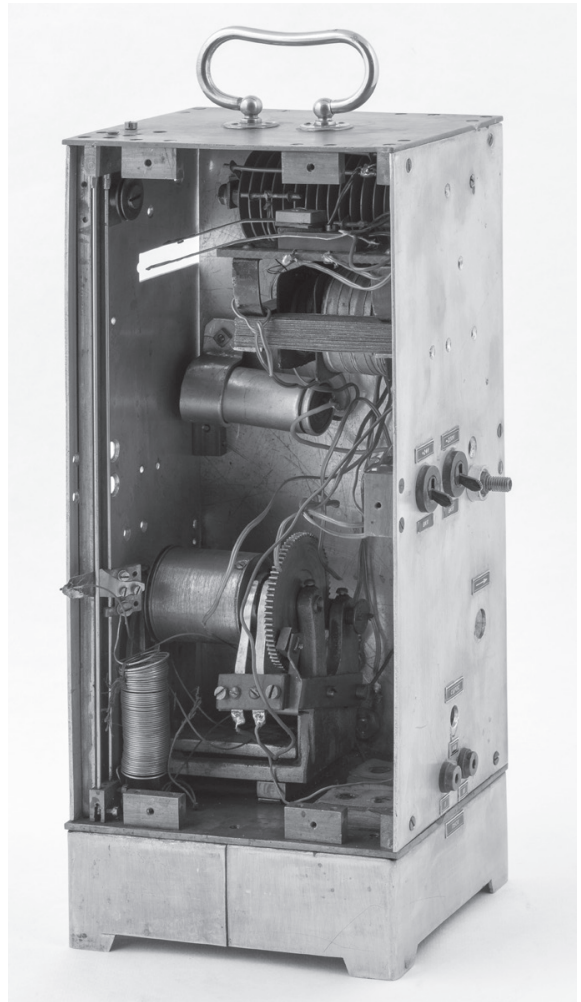

Figure 2. Pulse time recorder, or Pulszeitschreiber. Author: Alfred Fleisch. Tartu, 1930. (ÜAM 1229:1,2,4; 1150:57 AjM)

5 Automatic organ perfusion device, which was one of the first artificial blood circulation models alongside isolated lung. 


\section{Hugo Masing (1873-1939) as the maker of Fleisch's pulse time recorder}

In order to make his devices, especially the pulse time recorder, Fleisch used the services of precision mechanic Hugo Masing. Born in Tartu, Hugo Masing graduated from upper secondary school here and received his training in the workshop of the Tartu optic Bernhard Schulze, after which he furthered his theoretical knowledge in Germany. In 1901, Professor Boris Golitsyn (18621916) invited him to work at the Institute of Physics at the Imperial Academy of Sciences in St. Petersburg. There Masing managed to create his own workshop and developed into a valued precision mechanic. Masing's skills were challenged by the development of the technical designs of Golitsyn's horizontal and vertical seismographs, and it was complex to construct these as well. Masing's cooperation with Golitsyn was cut short by the professor's untimely death from a lung condition at the age of 54 . After the Russian Revolution and the restoration of independence of the Republic of Estonia, Masing and his family returned to his home town in 1920, taking the workshop's precious equipment with them. The new location for Werkstätten für Wissenschaftliche Instrumente Hugo Masing (Hugo Masing Workshop for Scientific Instruments) was Lai Street 17. When the physicist Johan Vilip (1870-1942) also arrived to Tartu from St. Petersburg (Professor of Physics at the University of Tartu 1920-1940) and improved the construction of vertical seismographs (doctoral thesis in $1930^{\circ}$ ), their production continued and the devices reached many places across the world.

In the mid-1930s, Hugo Masing was taken seriously ill, but somewhat recovered; his son Woldemar Masing replaced him at the workshop. The list of scientific equipment that was being made was expanded, commissions included analytical scales, anemographs, plane compasses, pulse time recorders- the latter of which were developed, improved and constructed by Professor Fleisch (ÜAM 942:1 Ar; Masing, 1985).

In October 1936, Fleisch ordered several pulse time recorders from Hugo Masing - ten iron cast ones "similar to the devices from the previous shipment", ten devices with an aluminium base and horizontal boards (which made the device lighter, thereby reducing issues with transport and customs), six devices in which the cast aluminium parts that Fleisch ordered would have been sent to

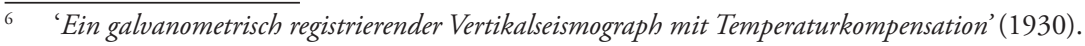


Tartu and Masing would be in charge of the completion of the device (ERA, 1936-1939).

Fleisch constantly improved the construction of the pulse time recorder. His orders were accompanied by additional blueprints done by engineer Armin Rhiener (he was also at the service of Fleisch in Tartu). The price of one such device was originally 288 kroons, but by 1939 the price had risen by 20 per cent. On 6 October 1938, Fleisch ordered four additional machines as Rhiner had yet again amended the blueprints. Two machines included in the order were completed in March 1939 (price approx. 345.60 kroons), and the rest in October 1939.

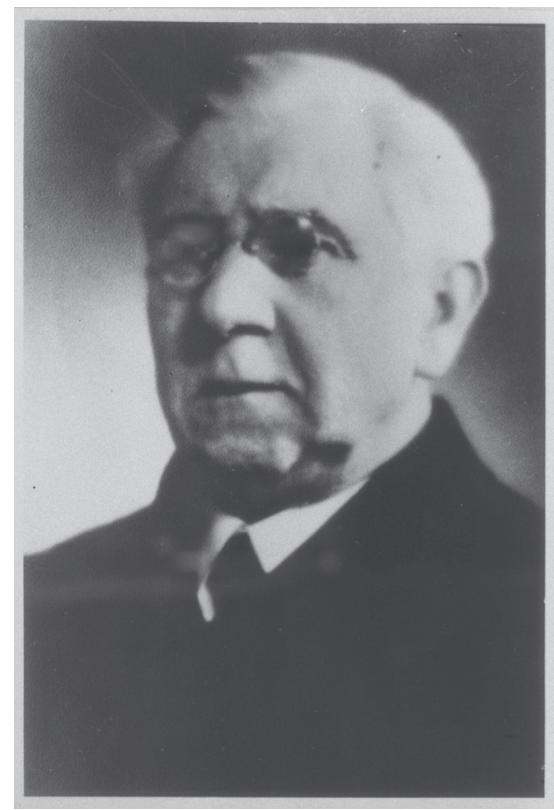

Figure 3. Hugo Masing (1873-1939). Fleisch confirmed in his letter from 11 May 1939 that two pulse time recorders had arrived in good condition and that two more would probably arrive soon; he also thanked Masing "für die prompte und gute Lieferung" (ERA, 1936-1939).

Based on the correspondence between Fleisch and Masing, approximately 30 pulse time recorders were completed between 1936 and 1939 but it is still unknown on the basis of data currently available to us how many machines were made prior to that (in the period of 1930-1935). Their relationship extended to the family level as well-Masing's son repeatedly visited with the Fleischs and during holidays the families sent greetings to each other. In October 1939, Masing announced of the liquidation of his company in Estonia and its relocation to Germany, shortly before that he delivered the last two pulse time recorders. (Masing handed the devices over to the Swiss consulate in Tallinn on 11 October 1939 before his departure. The consulate was supposed to deliver the machines to Professor Fleisch.) Those would be his final works—on 2 November 1939 he died, aged 66, in Gotenhafen, Germany. His workshop's equipment was destroyed in the war. 


\section{Maks Tiitso and physiology studies in the Estonian language}

After Fleisch's departure, the research direction of the Chair of Physiology passed on to his student Maks Tiitso, who had begun his work at the Institute of Physiology already as a student under Professor Lipschütz. As a junior assistant, Tiitso was able to improve his skills as a recipient of the Rockefeller Foundation scholarship in 1925 at the University of Toronto under the guidance of J. J. R. Macleod $^{7}$ and in 1926 at Harvard University at the Institute of Biochemistry under the guidance of $\mathrm{O}$. Folin.

Maks Tiitso led the Institute of Physiology during the years 1934-1944 (as Private Associate Professor in 1935, professor extraordinarius in 1939). He was the first at the University of Tartu to teach the full course of physiology and physical chemistry in Estonian, and he bore the full weight of developing terminology. It can be believed that Tiitso, who had a good international preparation, conducted lectures of physiology and physical chemistry just as well in Estonian as his predecessors had done in German (Kingisepp, 2005, p. 119). As a representative of a new generation of researchers, he was "youthfully enthusiastic, had a sportive character, was modern and logical in his lectures" (Käbin, 1986, p. 437).

Research-wise, he continued the direction started by Professor Fleisch at the University of Tartu. Tiitso studied the effect of insulin on saccharide metabolism, respiratory regulation, respiration and heartbeat during physical stress. His interests included physical education and sports. He was the first to use the pneumotachometre and the Pulszeitschreiber in experiments (which he adapted for animal experimentation). In order to do that, he constructed a simple veloergometer, which was essentially a bicycle attached to a base, with a shaft in the place of its back wheel, over which ran a rope that could be used to increase friction and thereby the exercise load (Acquisition documents..., 1983, pp. 6667). ${ }^{9}$ In 1933, the Institute of Physiology was named one of the three chairs of the Faculty of Medicine (together with neurology and pharmacology), where fundamental research took place (Universitas Tartuensis, 1632-2007, p. 352) according to a report by officials from the Rockefeller Foundation visiting the

7 James J. R. Macleod and Frederick G. Banting won the Nobel Prize in 1923 for the discovery of insulin.

8 Several authorised lecture notes of Tiitso's lectures have been stored in the University of Tartu Library (J. Tammeorg (1937), P. Holvandus (1938), etc.).

9 According to P-H. Kingisepp, Tiitso's veloergometer is in the collections of the University of Tartu Museum with a tag ÜAM 259:11 AjM. The veloergometer was improved in 1962 by adding new measuring equipment. The bicycle's frame and older equipment on the base (together with a proposed original marking) are covered with dark blue paint. 
University of Tartu. Tiitso left for Sweden in 1944, but was involved in an accident on the way and died in Stockholm on 2 October the same year.

\section{The development of Fleisch's academic legacy in physiological research and device construction}

Professor Fleisch's impact on the development of physiology and medical science at the University of Tartu continued. The scientific methods he developed for studying respiratory and blood circulation functions and the devices he constructed were used in many defended candidate and doctoral dissertations in specialised fields of medicine in the second half of the $20^{\text {th }}$ century.

After World War II, both the University of Tartu and the Institute of Physiology were at a crossroads. Former lecturers had left; research connections with the outside world had been severed. Once again, help arrived in the form of Fleisch's devices: the pulse time recorder (interval recorder) and the pneumotachometre. Using those two devices, a total of 12 dissertations were defended at the Faculty of Medicine during the following years. If we add the theses using Professor Fleisch's methods and ideas, the number reaches 20. Alfred Fleisch can be rightfully considered the professor whose teachings created a pool of Estonian researchers who explored physiology and biochemistry in Estonian (Looga, 1975 , p. 22).

Hugo Vihvelin (1906-2007) and Alfred Molle (1910-1998) defended their theses in the late 1940s. Both left Estonia in 1944 and later continued their work in Canada.

In the second half of the $20^{\text {th }}$ century, Maria Epler (Reeben) (1920-2000), Olaf Imelik (1923-2014), Ülo Lepp (1917-2003), Robert Looga, Erich Môtlik (1912-1998), Jaan Riiv (1919-1995), Ants Rulli (1908-1986), Juhan Unger (born 1931), Jüri Saarma (1921-2001), Helga Sildmäe (1927-1995), AtkoMeeme Viru and Peet-Henn Kingisepp defended their candidate or doctoral dissertations at Tartu State University. 


\section{Research using the pulse time recorder and new constructed devices}

The research series was started by the future Professor of Surgery Ants Rulli, who defended a Candidate of Medical Sciences dissertation on 27 July 1947 (the first dissertation of its kind at the university). The work analysed the following problem: what is the significance of vagus nerve's innervating nerve branches on the relationship of heartbeat frequency and respiratory rate. The dissertation was based on research done before the war at the Laboratory of Physiology under the instruction of Professor Maks Tiitso, the protocols of which had been preserved and included the respiratory and heart rates of 21 test animals ( $\mathrm{dogs}$ ) recorded on carbon paper, before and after vagotomy (severing of the vagus nerve, a cranial nerve that eliminates the effect of the vagus nerve). Rulli used Tiitso's version of the pulse time recorder, which could be used in animal experiments. Research material, which had been compiled about ten years before, proved to be novel and "actually very good" for the dissertation (Rulli, 2008, p. 90).

In 1950s, Rulli, later Professor of General Surgery (in 1945-1954, 19571974), began to plan a new research work, which would be tied to research on circulation and the constant measuring and monitoring of pulse and blood pressure during various manipulations. It is possible that he was inspired by the doctoral thesis of Valter Hiie defended in 1932 'On pulse time oscillation at the time of anaesthesia and in various stages after the anaesthesia'. For that purpose, Rulli constructed a bloodless constant blood pressure recorder, and an interval tonometer (which recorded arterial pressure and intervals between two heartbeats) based on Fleisch's pulse time recorder (interval recorder). The device's first and second (working) models were completed at the university's workshop by radio technician Voldemar Kiis and mechanic Arnold Susi. ${ }^{10}$ Rulli's doctoral dissertation (defended at the Tartu State University Council of the Faculty of Medicine on 21 June 1968), describing and analysing the fluctuations in arterial blood pressure and pulse rates during operations with local anaesthesia, is based on the interval tonometer. The experiments were carried out at the surgical departments of the Toome and Maarjamóisa hospitals in Tartu, the in-patient department of the tuberculosis dispensary of Tartu and the study base of the Chair of Hospital Surgery of the First Medical Institute of Leningrad (Rulli, 2008, p. 149).

10 The interval tonometer was shown in Moscow during a pan-Union exhibition of industrial and agricultural achievements (1955); there were people interested in commissioning one, but at the time the production of the device was not feasible. 
Maria Epler, at the time an assistant at the Chair of Physiology, later Associate Professor and Research Director of the Laboratory of Biophysics, used Alfred Fleisch's pulse time recorder in her work to study the oculocardiac reflex (pressure on the eyes causing a decrease in pulse rate) and to describe the characteristic dynamics of the reflex (Candidate of Medical Sciences degree in 1954).

In his candidate and doctoral dissertations, Robert Looga also continued the same traditions and research directions that were started by Professor Fleisch in 1928. In 1954, Looga completed his candidate dissertation on the topic 'Reflectory changes in heart rate during increased pressure'. The research was targeted at identifying changes in cardiac and circulatory processes during raised pressure in the lungs, and the Pulszeitschreiber was one of the key experimental instruments. In his doctoral thesis 'The influence of changes in lung volume and pulmonary circulation on systemic circulation and respiration' (defended in Leningrad in 1970), he continued that line of research. Starting from 1955, Looga taught a course in pathological physiology as an experimental preclinical discipline for over 30 years at the University of Tartu, Faculty of Medicine, passing knowledge about the formation and development mechanisms of diseases onto several generations of doctors.

Jaan Riiv, later professor and head of the Chair of Propaedeutics of Internal Diseases (1961-1988), discussed sleep therapy in his Candidate of Medical Sciences dissertation ('Clinical observations on the duration of sleep and upon the research of some vegetative indicators, especially in connection to sedative ingestion', 1958). Once again, Fleisch's device was used to record heart rate. It showed that under the influence of sedatives, heart rate fell and the extent of respiratory arrhythmia lessened.

Ülo Lepp, later Associate Professor of the Chair of Internal Diseases and the Centre of Cardiology (1960-1991) dedicated his candidate dissertation (defended in 1953) to studying the haemodynamics of hypertonia patients using the Pulszeitschreiber.

Juhan Unger, a lecturer of the Department of Physical Education of Tartu State University (in 1954-1973) and later the head of the Chair of Sports Games and Athletics at Tallinn Pedagogical University (in 1984-1991), used Fleisch's Pulszeitschreiber in his work as well. His task was to identify the dynamics of heart activity during an active rest experiment (the dissertation was defended in 1969). In order to do that, he and the chair's technician Evald Lall constructed an installation for lifting weights by pressing pedals with feet. It was possible 


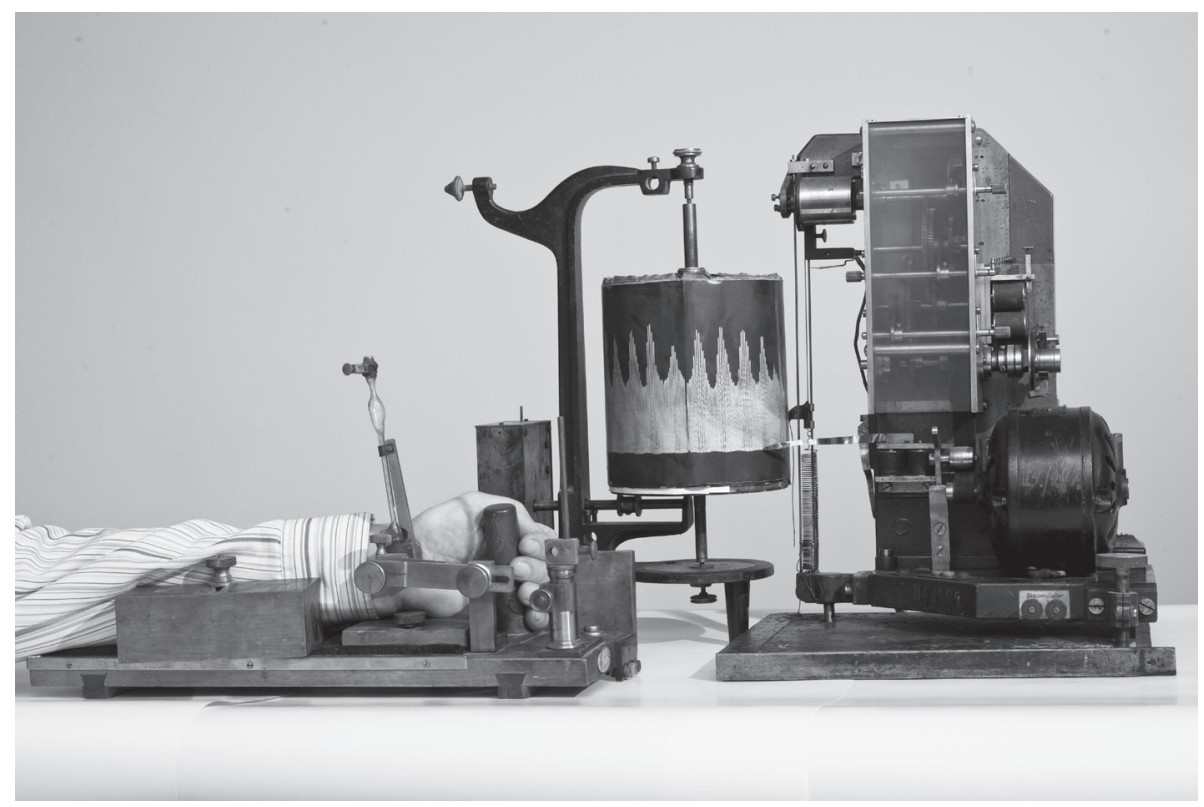

Figure 4. Pulse time recorder, i.e. cardiotachometer-interval recorder. The development of Fleisch's method. Authors: Vello Reeben, Juhan Unger. Tartu, 1960 s. (ÜAM 1229:8 AjM)

to use one and the other foot intermittently, or both at the same time. But Unger was not satisfied with only a laboratory experiment. He was thinking of outputs in practical sports. To achieve that, he needed to improve the methods of recording heart activity. Such an opportunity presented itself in the form of using biopotentials accompanying heart contractions instead of arterial oscillations. Unger became a daily "visitor" to the university's experimental workshop. Vello Reeben's constructor talent solved the problem yet again and in a year they had a device that retained Fleisch's principle-recording of time as a vertical line between two heart contractions, but ECG chest electrodes were used as detectors. By using this method it became possible to observe stress of subjects on a veloergometer and test the effect of drastic exertion. In principle, it enabled to register heart activity during various sports exercises (Viru, 2006, pp. 180-185).

Atko Viru, later Professor of Sport Physiology and Dean of the Faculty of Physical Education (in 1973-1989), used the possibilities of Fleisch's pulse time recorder both in compiling his candidate and doctoral dissertations (defended in 1963 and 1970). He wrote: 
As a student, I became closely acquainted with Fleisch's pulse time recorder. This device for registering heart rate dynamics was unique at the time and had never been mass produced. Its main value lies in the fact that even the tiniest heart rate fluctuation is visible with the naked eye, because the device registered the duration of each heart cycle (pulse time). It was self-evident that my dissertation also had to be based on the study of heart activity during physical duress while using this device (Viru, 2006, p. 195).

With the help of the device, Viru studied the effects that forced expiration has on heart rate recovery after physical activity; this was also a continuation of the subject of the 1935 publication by Tiitso and Pehap (1935, pp. 51-61). A step forward in Viru's research was studying an athlete's condition before the start, for which the author used the cardiotachometer-interval recorder constructed by Unger and Reeben (see Fig. 4).

The Chair of Sports Medicine and Physiotherapy was created in 1961 as a part of the Faculty of Physical Education under the initiative of Fred Kudu (19171988) to promote research in the field of sports physiology and the preparation of sports physicians (in 1970 it was merged with the Faculty of Medicine, under the head Toomas Karu). The position of the first head of the chair was offered to the correspondent member of the Estonian Academy of Sciences, Professor Ilo Sibul (in 1964-1966), whose research career had begun as Fleisch's assistant. As we have mentioned before, Ilo Sibul participated in Fleisch's research, as a result of which the role of metabolism products on tissue blood supply regulation was proven.

Professor Ilo Sibul was the supervisor of research done by Helga Sildmäe (in 1950-1971 senior teacher at the Chair of Skiing of Tartu State University, in 1971 Associate Professor), who had, using a telemetric device, gathered data on heart rate dynamics in ski athletes. The results contradicted the theory that a high pulse rate (over 200) is common to well-trained athletes, which was widely accepted at the time. Sildmäe's results demonstrated that high pulse rates occur in poorly trained athletes, who are able to put in some effort, but whose cardiovascular system's functional abilities are not high. (Viru, 2007, p. 230) Sildmäe defended the degree of Candidate of Biology in 1964.

Under the supervision of Karu, several applied contractual works in the fields of work physiology and device construction were written during the years 19701985 (Maaroos, 2007, p. 379). Physiologists also participated in research on the external respiration of skiers, decathletes, runners and swimmers alike, analysing 


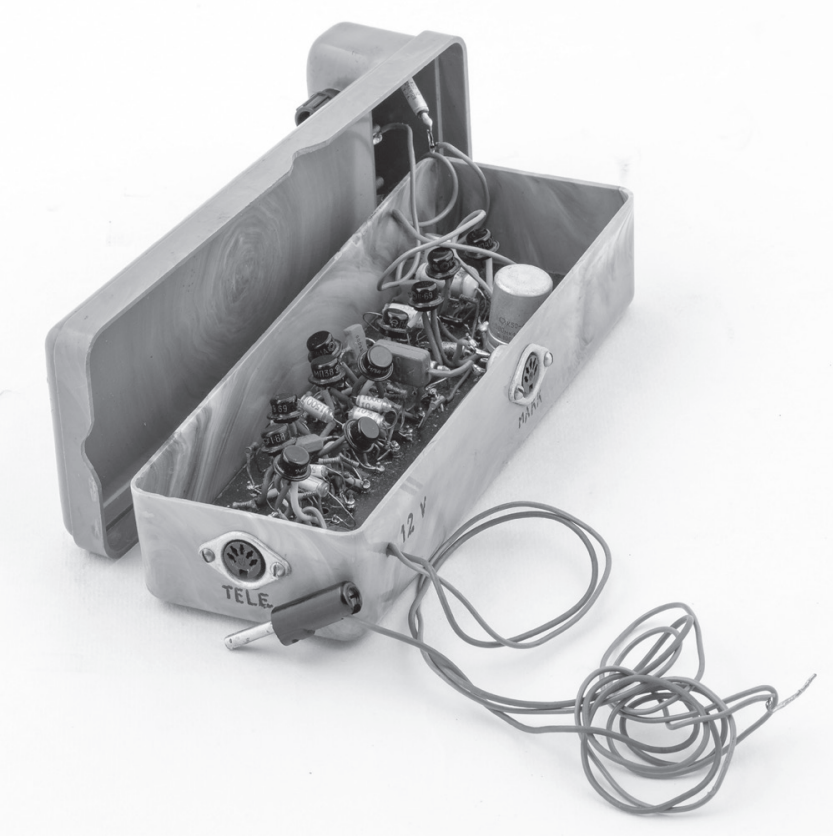

Figure 5. Tele-electrocardiograph for telemetric pulse rate regulation. Authors: Leo-Henn Humal, Toomas Karu. Tartu, 1970s. (ÜAM 1557:1/a-d AjM) the connection between the level of training and athletic achievements (Vasar et al., 2007, pp. 108-109). Nowadays as well, the Institute of Exercise Biology of the University of Tartu continues research into the hormonal $\mathrm{regul}$ a $\mathrm{t}$ i o $\mathrm{n}$ of muscles, physiology of the neuromuscular system and the physiologicalb i o che m i c a l monitoring of training, as well as

the effect of diet-related factors on physical performance and the efficiency of training (Ööpik, Pääsuke \& Seene, 2005, p. 59).

The laboratories of biophysics and electrophysiology, created as a part of the Chair of Physiology in 1962, received fairly good and modern equipment for studying the cardiopulmonary system and respiratory functions, as the developing research activity created the demand for improving existing devices and constructing completely new ones. Many of them included assemblies similar to Fleisch's Pulszeitschreiber, but owing to the developments in technology, they were more compact. In the years 1962-1999, the Laboratory of Biophysics developed or was in the process of developing various original circulatory and respiratory system indicator measuring equipment: average blood pressure recorder, ECG T-wave amplitude and QT interval analyser, cardiotachograph, veloergometer, a 12-channel circulatory and respiratory system indicator recorder, a pneumotachograph, Foucault's cardiograph (Jüri Vedru), skin blood flow thermal clearance recorder (Rein Raamat), etc. 


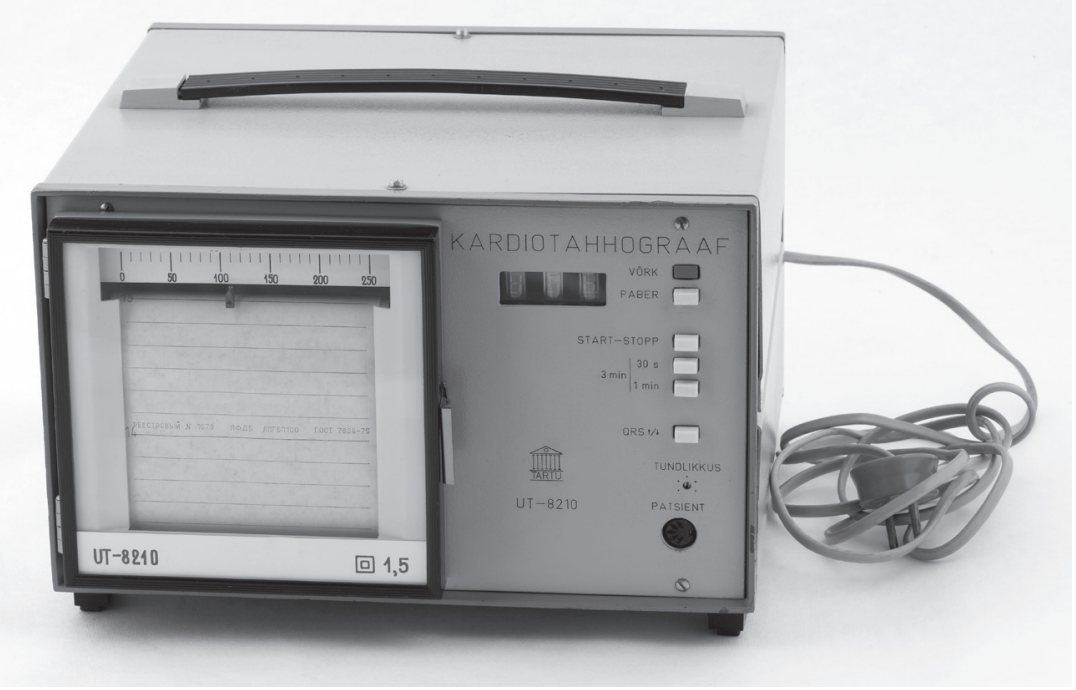

Figure 6. Cardiotachograph UT-8210. Authors: the sports medicine work group of the University of Tartu, Leo-Henn Humal, Jüri Vedru, etc. Tartu 1982. (ÜAM 1178:1 AjM)

One of the devices most often displayed at international exhibitions is the cardiotachograph UT-7404 (1974), improved version UT-8210 (1982). The device made it possible to run stress tests to determine the condition of the cardiovascular system-to measure and register heart indicators, calculate the duration of cardiac cycles during a certain time period and display heartbeat visually. The cardiotachograph UT-7404 made it possible to achieve great measurement precision and dependability alongside easy regulation and use; electrodes connected to the patient's body sent out an input signal, enabling the monitoring and constant recording of the pulse rate in different situations, including during implementing maximal exercise load on the veloergometer (Archives of the University of Tartu Museum, ÜAM 1178:2/1,3Ar, Humal, Vedru). The cardiotachograph was displayed at the U.S.S.R.'s Exhibition of Achievements of the People's Economy (small gold medal), the U.S.S.R. exhibition in Kabul (1979), Brussels and Los Angeles.

The biophysics laboratory also developed a non-invasive differential oscillometric method for measuring average arterial blood pressure, based on the Marley principle (the Reeben-Epler method) (Vasar et al., 2007, p. 110). The recorder using this principle was fast, allowing it to measure the average blood pressure of each cardiac cycle. The new technology attracted plenty of interest, which 
is why the devices that became known as the 'Füsiograaf UT' were made at the university's experimental workshop for more than 30 leading research centres and universities in the Soviet Union. Leningrad's production centre "Krasnogvardeets" tried to start mass producing the device, but the relatively complex symbiosis of pneumatics and electronics proved too difficult for the Soviet experimental factory at that time.

The speedy and constant recording of blood pressure created the opportunity to study blood pressure dynamics in the conditions of a fluctuating load more precisely (Kersti Jagomägi's candidate dissertation studied a load with sinusoidal fluctuation, 1975; she also used the pneumotachograph in research on gas exchange). Various load regimes were generated and modelled with the help of computers by the engineers Peeter Loog and Enn Hendrikson.

Owing to the emergence of new opportunities during the last decade of the $20^{\text {th }}$ century, it also became possible to test the medical equipment developed and built at the University of Tartu in leading European universities and research centres. The new model of the constant blood pressure recorder (authors: Associate Professor Jaak Talts, Rein Raamat, Kersti Jagomägi) has been repeatedly tested and compared with internationally renowned devices Finapres and Portapres at the Kuopio University Hospital (Prof. Esko Länsimies), Centre for Fundamental Research at the University of Oslo (Prof. Lars Walloe), Department of Biomedical Engineering of the University of Linköping (Prof. Ake Öberg). The results of joint research have shown that the device created in Tartu is suitable for physiological studies (Jagomägi et al., 1996, pp. 551-560; Raamat et al., 2001, N13-N20).

\section{Research using the pneumotachograph and new constructed devices}

The second device of Fleisch's Tartu period - the pneumotachometre, which brought him international fame-made it possible to measure the dynamics of the air flow volume rate during breathing as a brain function, and thereby also measure the respiratory flow volumes.

The pneumotachometre was used in research by Olaf Imelik, who initiated sports physiology research in post-war Estonia (he later worked as an Associate Professor at the Tallinn Pedagogical University and the Chair of Physiology at the University of Tartu). In addition to Fleisch's legacy, Imelik used the veloergometer 
constructed by Tiitso, who published the first work on that topic in 1935 (Tiitso, 1935, pp. 16-26). It was Maks Tiitso who began to use the pneumotachometre to study changes in respiration caused by physical activity. Imelik, who had been at Tiitso's lectures as a student, directly continued the work Tiitso had started in the dissertation he defended in 1955 ('The changes in respiratory function during physical labour').

The aim of Erich Mótlik, later Vice Dean of the Faculty of Physical Culture, wanted to teach swimmers the proper breathing technique. In order to do that he constructed a portative pneumotachometre that could record shallow and diaphragmatic breathing in parallel (description of the device in 1961). That was the topic of his Pedagogics Candidate dissertation, defended in 1955.

The candidate and doctorate dissertations (defended in 1960 and 1973) of Elmar Vasar, later Professor of Physiology and head of the Chair of Physiology (in 1975-1991) focused on research on spirography and pneumotachometry (recording and analysing spirographic indicators of breathing externally). The candidate thesis (1973) of Peet-Henn Kingisepp, later Associate Professor of the Institute of Physiology analysed the fluctuations in gas exchange and acid-alkali state during repeated physical labour. Associate Professor Jana Kivistik worked on developing the norm value of external respiration in children. Her research include measurements on children suffering from asthma, for which she used recording pressure oscillations caused by the inhibited air flow fluctuations in addition to pneumotachometric measurements (Kivastik, Gibson \& Primhak, 2006, pp. 145-150; Kivistik et al., 2014, pp. 247-252). This enables to determine breathing resistance in small children.

Fleisch's or other kinds of pneumotachometric principles have been used and further developed in Tartu by the physicist Leo-Henn Humal, engineer (Candidate of Technical Sciences) Rein Raamat, electric engineer Vello Reeben, Maria Epler, Toivo Sermat, Peet-Henn Kingisepp and Jürgen Lamp (Kingisepp, 1993, pp. 210-214).

The improvements in the methods of spirographic studies led to the construction of a fully automated spiroanalyser (SA-03) in cooperation between the Institute of Physiology and Laboratory of Electroluminescence and Semiconductors of the University of Tartu in the early 1980s. The automatic system device for studying breathing function involved the creation of a corresponding detector, entering the base data, the creation of programmes (software) based on algorithms, checking the system's precision of measurement. Engineers Jürgen Lamp, Peeter Plakk 


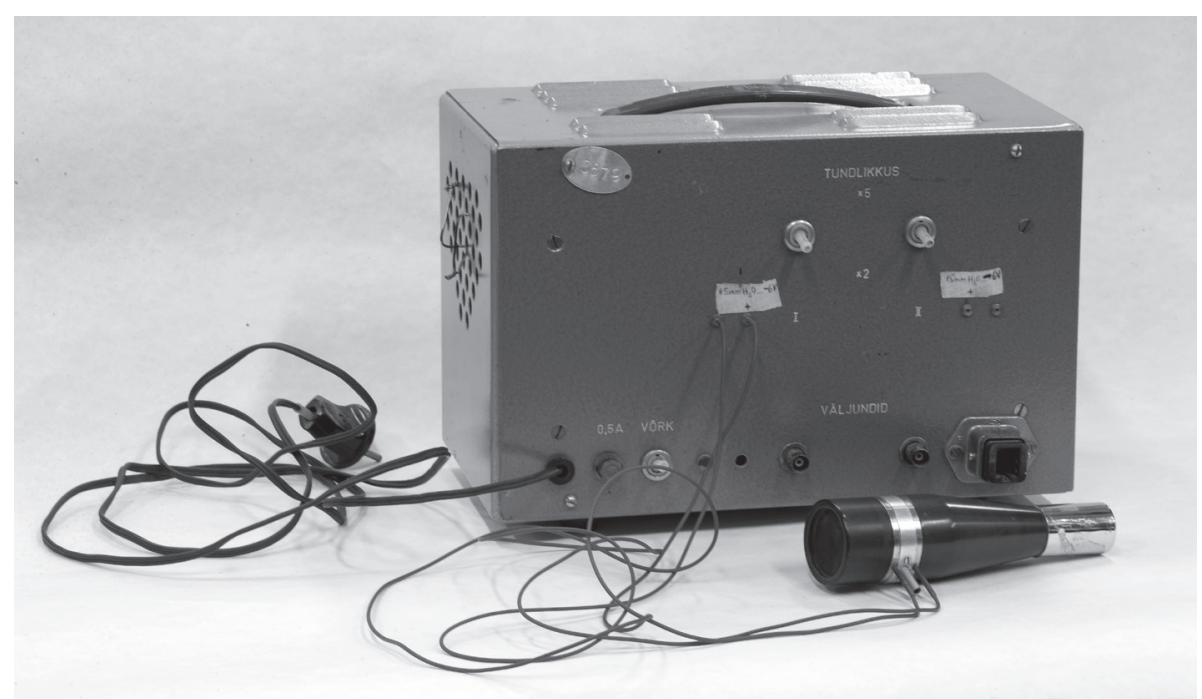

Figure 7. Pneumotachometre B4-2 for measuring respiratory air flow in the Fleisch way. The Laboratory of Biophysics of the University of Tartu, 1970. Authors: Rein Raamat, Toivo Sermat. Air flow is measured according to the pressure difference that appears during the air's laminar flow in tubes. (ÜAM 1505:16 AjM)

and Peeter Liik participated in the development of the device. The Institute of Physiology compiled the software's algorithms and checked the analyser. The device was used at the Tartu Lung Clinic, Tallinn Clinic of Occupational Diseases and Tallinn Tuberculosis Dispensary (Kingisepp \& Lamp, 1991, pp. 334-337).

Unfortunately, many of the devices constructed at Tartu State University remained unknown to a wider public because U.S.S.R. was closed to the outside world. The publications on the devices (mainly in Russian) did not reach international readers.

Nevertheless, several of the devices (cardiotachograph models, etc.) received diplomas and acknowledgement at the U.S.S.R. Exhibition of Achievements of the People's Economy (cardiotachograph UT-7404—small gold medal (1978)). The devices' creators earned praise as well-this is how the employees of the Laboratory of Biophysics Vello Reeben and Rein Raamat both received over ten U.S.S.R. Author's Certificates in the field of scientific machine-building and measuring method development (Institute of Physiology, 2007, p. 110).

Several of the devices were mass produced in the factories and companies of Estonia, the U.S.S.R. and the Social-democratic countries. Those included 
the electrocardiograph EKCMP-H3050 (Krasnodarskii ZIP, 1987), electromechanical calculator (Büromaschinen Export GMBH Berlin, DDR), physiological rheograph PG4-01 (1979) and many others that were developed at the Laboratory of Physiology of the University of Tartu (Acquisition documents..., 2011, pp. 129-134).

There were times when the research developed using the created devices remained unrealised. According to Viru:

Thinking back on the results the use of the cardiotachograph has given us, I feel growing regret that we did not have enough self-awareness or publication skills at the time. For example, the study on swimmers produced a surprising result - that heart rate slowed while diving. Even though the cardiotachograph produced clear results, we had doubts and searched for recording errors. The interesting result remained known to us alone. Two years later, a central international magazine published an article on the slowing of heart rate in sea lions during underwater swimming. After that, several articles confirmed the same in professional divers. We had let the right time slip by. The results would have received international attention. (Viru, 2006, p. 206)

By now, most of those devices have found their way into the collections of the University of Tartu Museum as a memorial of the long-time research we have conducted. The compiled works (candidate and doctoral dissertations) show the directions of research of the time, the way problems were stated and solutions achieved.

\section{"Every researcher carries a grain of sand, only a few ones also have a stone"}

Alfred Fleisch developed into an outstanding researcher owing to multifaceted professional preparation, profound interest in physiological problems and great work capacity.

He drew attention already as a student. After passing national exams and defending his dissertation, ${ }^{11}$ he was offered the position of an assistant at the medical polyclinic of Zurich, at the institutes of pathology and physiology and

$\overline{11}$ 'Über die Koblensäurewirkung auf die Blutgefässe' (1917). 
even in the surgery clinic under the lead of Professor F. Sauerbruch. The latter would later speak of his hapless assistants while working in Berlin and said that one of his students had a talent for surgery, but "he is sitting in Tartu and killing rabbits" (Fleisch, 1972, p. 74).

During his short time at the University of Tartu, Fleisch managed to influence both his colleagues and students. The head of the Children's Clinic of the University of Tartu Dr. Lüüs wrote:

Professor Fleisch soon earned the trust of both his colleagues and students. He was impeccable as an academician and teacher. While in Tartu, he constructed a device for measuring blood pressure, which began to be used in various locations both in Estonia and abroad. When he left, the chair held a dinner where I as the dean thanked him for "trying to follow in the footsteps of former great physiologists who worked at the University of Tartu”. (Lüüs, 1959, p. 103)

Professor of Surgery Ants Rulli wrote:

Fleisch's physiology lectures were in German, which made it somewhat hard to understand, yet the style of the presentation and the professor's clear speech, as well as many demonstrations on animals, made the lecture understandable even for those with a weak grasp on German (Rulli, 2008, pp. 45-47).

Trainees were instructed by the assistants Maks Tiitso and Ilo Sibul, but the professor himself was always present and watched the students' work. Rulli even had to re-take the physiology exam, as his answer in the first one was not considered sufficient. It is possible that a closer contact with physiology caused by the repeated exam and the example of Fleisch, Tiitso and Sibul would eventually pave the way for Rulli's research work (Peetsalu, 2008, p. 161).

Alfred Fleisch was a great example for those wishing to dedicate themselves to research and experimentation. According to Atko Viru, the most internationally known Estonian sports physiologist, the use of Fleisch's devices took research to a level higher than the average at the time. The pulse time recorder, which registers the durations of cardiac cycles in parallel vertical lines, earned the most attention. It makes pulse time dynamics easy to monitor and analyse over longer periods of time. At the time there were no alternatives for studying the duration of the cardiac cycle in longer experiments and the important issues of cardiac regulation had not been studied much (Viru, 2001, pp. 43-55). 
Alfred Fleisch's Ordinat-Zeitschreiber method has found overall recognition and use in medicine. And even though there have been many new propositions to modernise and modify the device using modern electrotechnology and electronics, according to Robert Looga (1975, p. 29), Fleisch's original purely mechanic construction has proven to be the most reliable and trustworthy over time.

Rein Raamat was also impressed by Fleisch's ingenious idea for the ordinate writer-using fairly simple tools (an electric motor moving the quill at a constant speed and a few electromagnets) it was possible to show the entire dynamics of heart rate fluctuations. And writing on carbon paper produced a very clear result, even though everything was covered in soot. He agreed with Looga's opinion that in 1975 and even after that, Fleisch's pulse time recorder remained completely competitive and outperformed Soviet electrical solutions with its reliability. But the later development of electronics and especially computer sciences have changed the situation a lot-nowadays all it takes to record pulse time is to attach electrodes to the body, electronics and computer processing take care of the rest. There is no need to use moving electromechanical assemblies like engines, electromagnets, etc.

Alfred Fleisch was very surprised when the University of Tartu, under the initiative of Professor Robert Looga congratulated him on his $75^{\text {th }}$ birthday at the end of 1967. He replied: "I consider the years spent in Tartu the most beautiful years of my life. The university management of the time showed great understanding towards my applications concerning the work organisation of the institute so that I, alongside my Estonian assistants, could work successfully." (Kulo, 1967)

\section{In conclusion}

Professor Fleisch's pedagogical activity and research achievements have influenced the development of Estonian physiology decades after his departure from the University of Tartu. Rudolf Tamm (1886-1946), the assistant of the Institute of Physiology (1919), and Maks Tiitso were the first Estonians to be employed in academic positions at the Institute of Physiology of the University of Tartu. The arrival of the post-war generation into the research on physiology in the mid-1940s signified a new era in physiology. This generation's choice of research topics was strongly influenced by Professor Fleisch's ideas and the devices he 
constructed (Kingisepp, 2011, p. 36). The end of that era in the early 1990s coincides with the emergence of a new generation at the institute and on the arena of national physiology.

At the University of Tartu, as well as everywhere else in the world, the physiological research done today is mainly characterised by the topics concerned with the cell and molecular level, the amount of research done on the level of an organism as a whole has diminished. This is the natural course of things, as the latter direction was the focus of research in the world for decades, and satisfactory devices measuring blood pressure both in clinical practice and during home use have been developed.

As the oscillometric measurement device (one modification of which is also the quick differential oscillometric measurement device developed in Tartu) is the noninvasive blood pressure measuring device with the largest production volumes in the world, it is possible to understand the public interest towards these measurement devices' precision and dependability. The development of oscillometric measuring methods and precision analysis using computer simulations have been this direction's further developments at the Institute of Physiology of the University of Tartu (Raamat et al., 2011, pp. 238-245; 2013, pp. 50-56).

In the field of machine construction, the Institute of Physiology of the University of Tartu is engaged in a collaborative project to create a quick blood pressure meter to be used in CT studies (leader on the part of the University of Tartu is Associate Professor Jaak Talts). This meter must be able to work in the Faraday chamber in an extremely strong magnetic field. According to the project's main leader, Dr. Alex Jones (University College London), the device developed in Tartu has the highest potential among several competitors to become the desired MRI niche product.

\section{Acknowledgments}

I am thankful to Rein Raamat, a specialist of the Department of Physiology of the University of Tartu and a Candidate of Technology, for his advice on handling the topics of machine construction. 


\section{References}

Acquisition documents of the University of Tartu Museum (1983), Tartu Ülikooli muuseumi vastuvôtuaktid, University of Tartu Museum.

(2011), Tartu Ülikooli muuseumi vastuvótuaktid, University of Tartu Museum, Tartu.

EAA (1926-1932), 'Fleisch, Alfred,' personal file, EAA f 2100, n 5, s 130, Estonian Historical Archives, Tartu.

ERA (1936-1939), Correspondence with foreign companies and scientific research establishments on the topic of the founding and activities of seismographic stations, commissioning of, and cooperation on the topic of seismographs and galvanometers and other precision instruments, ERA f 3103, n 1, s 4, Estonian State Archives, Tartu.

Fleisch,A. (1925), 'Der Pneumotachograph; ein Apparatzur Geschwindigkeitsregistrierung der Atemluft,' Pflügers Archiv für die gesamte Physiologie des Menschen und der Tiere, vol. 209, pp. 713-722. http://dx.doi.org/10.1007/BF01730956

(1930), 'Der Pulszeitschreiber; ein Apparat zur Aufzeichnung der Zeitlichen Pulsintervalle als Ordinate, Zeitschrift für die Gesamte Experimentelle Medizin,' vol. 72, pp. 384-400. http://dx.doi.org/10.1007/BF02623250

- (1930), 'Zur Methodik der Pneumotachographie,' Pflügers Archiv für die gesamte Physiologie des Menschen und der Tiere, vol. 223, pp. 364-368. http://dx.doi.org/10.1007/BF01794093

(1972), Geschichte der Familie Fleisch, Frauenfeld: Huber \& Co.

Fleisch, A. \& Sibul, I. (1933), 'Über nutritive Kreislaufregulierung II,' Pflügers Archiv für die gesamte Physiologie des Menschen und der Tiere, vol. 231, no. 6, pp. 787-804. http://dx.doi.org/10.1007/BF01754590

Fleisch, A.; Sibul, I. \& Ponomarev, V. (1932), 'Über nutritive Kreislaufregulierung I,' Pflügers Archiv für die gesamte Physiologie des Menschen und der Tiere, vol. 230, no. 5/6, pp. 814-834. http://dx.doi.org/10.1007/BF01752036

Humal, L-H. \& Vedru, J. (1975), Väikesegabariidiline kardiotahhograaf [A Small-Gauge Cardiotachometer], Manuscript, ÜAM 1178:2/1,3 Ar, The University of Tartu Museum Archives, Tartu.

Jagomägi, K.; Talts, J.; Raamat, R. \& Länsimies, E. (1996), 'Continuous non-invasive measurement of mean blood pressure in fingers by volume-clamp and differential oscillometric method,' Clinical Physiology, vol. 16, no. 5, pp. 551-560. http://dx.doi.org/10.1111/j.1475-097X.1996.tb01020.x

Käbin, I. (1986), Die Medizinische Forschung und Lehre an der Universität Dorpat/Tartu 1802-1940: Ergebnisse und Bedeutung für die Entwicklung der Medizin, Lüneburg: Nordostdeutsches Kulturwerk.

Kalling, K. (2007), 'Teadustöö arstiteaduskonnas 1920.-1930. aastatel' [Research at the Faculty of Medicine during 1920s-1930s], in T. Hiio, H. Piirimäe (eds.) Universitas Tartuensis 1632-2007, Tartu: University of Tartu Press, pp. 352-353. 
Kingisepp, P-H. (1993), 'Alfred Fleisch 100,' Eesti Arst, no. 3, pp. 210-214.

(1997), 'Füsioloogia ôpetamisest Tartu Ülikoolis ajavahemikul 1919-1940' [Physiology studies at the University of Tartu in the years 1919-1940], The University of Tartu Historical Topics XXIX (75 years of an Estonian university in Tartu), pp. 164-172.

(2005), 'Maks Tiitso - esimene eestlasest füsioloogiaprofessor Tartu Ülikoolis' [Maks Tiitso- the first Estonian Professor of Physiology at the University of Tartu], The University of Tartu Historical Topics XXXIV, University of Tartu, pp. 109-123.

(2011), 'Alfred Fleisch (1892-1973): Professor of Physiology at the University of Tartu, Estonia,' Journal of Medical Biography, vol. 19, pp. 34-37. http://dx.doi.org/10.1258/jmb.2010.010039

Kingisepp, P-H. \& Lamp, J. (1991), 'Välise hingamise parameetrite muutmine automaatspiroanalüsaatoriga UT-8911' [Changing the parameters of external respiration with an automated spiroanalyser UT-8911], Eesti Arst, no. 5, pp. 334-337.

Kivastik, J.; Gibson, A. M. \& Primhak, R. A. (2006), 'Feasibility of shortened methacholine challenge in preschool children,' Pediatric Pulmonology, vol. 41, no. 2, pp. 146-150. http://dx.doi.org/10.1002/ppul.20341

Kivastik, J.; Talts, J.; Jagomägi, K. \& Raamat, R. (2014), 'Interrupter technique for assessing respiratory resistance: a review,' Proceedings of the Estonian Academy of Sciences, vol. 63, pp. 247-252. http://dx.doi.org/10.3176/proc.2014.3.07

Kulo, H. (1967), Alfred Fleisch, professor, Sveitsi kodanik [Alfred Fleisch, professor, a Swiss citizen], Tartu: Tartu State University, 1 December.

Looga, R. (1975), 'Professor Alfred Fleisch Tartu Ülikooli füsioloogiainstituudi juhatajana' [Professor Alfred Fleisch as head of the Institute of Physiology of the University of Tartu], Tartu Ülikooli Ajaloo Küsimusi III [The University of Tartu Historical Topics III], Tartu, pp. 22-36.

Lüüs, A. (1959), Tartus ja Rootsis: eluradadel nähtut, kuuldut, meelespeetut [In Tartu and in Sweden. Seen, heard, remembered from the walks of life], Stockholm: Estonian publishing house EMP Stockholm.

Maaroos, J. (2007), 'Spordimeditsiini ja taastusravi kliinik' [The Sports Medicine and Rehabilitation Clinic], in K. Kalling (ed.) Tartu Ülikooli Arstiteaduskond 19822007 [The Faculty of Medicine of the University of Tartu 1982-2007], Tartu: Tartu Ülikooli Kirjastus, pp. 379-385.

Masing, W. (1985), Hugo Masing Leben und Werk als Konstrukteur und Erbauer von Erdbebenseismographen, Wetzlar, Manuscript, ÜAM 942:1 Ar, The University of Tartu Museum Archives, Tartu.

Ööpik, V.; Pääsuke, M. \& Seene, T. (2005), 'Spordifüsioloogiaalane uurimistöö Tartu Ülikooli Spordibioloogia ja füsioteraapia instituudis' [Sports physiology research at the Institute of Sports Biology and Physiotherapy of the University of Tartu], in A-E. Kaasik \& R. Uibo (eds.) Teadusmõte Eestis. Arstiteadus, Tallinn: Eesti Teaduste Akadeemia Kirjastus, pp. 59-70. 
Peetsalu, A. (2008), 'Ants Rulli 1908-1986,' in A. Velliste (ed.) Ants Rulli - kirurgia professor [Ants Rulli-Professor of Surgery], Tartu: Ecoprint, pp. 159-183.

Raamat, R.; Jagomägi, K.; Talts, J.; Toska, K. \& Walloe, L. (2001), 'Recording of short-term finger blood pressure changes induced by an arterial occlusive thigh cuff: Comparison between the modified oscillometric and Finapres techniques,' Physiological Measurement, vol. 22, no. 2, N13-N20.

http://dx.doi.org/10.1088/0967-3334/22/2/402

Raamat, R.; Talts, J.; Jagomägi, K. \& Kivastik, J. (2011), 'Errors of oscillometric blood pressure measurement as predicted by simulation,' Blood Pressure Monitoring, vol. 16, no. 5, pp. 238-245. http://dx.doi.org/10.1097/MBP.0b013e32834af752

- (2013), 'Accuracy of some algorithms to determine the oscillometric mean arterial pressure: a theoretical study,' Blood Pressure Monitoring, vol. 18, no. 1, pp. 50-56. http://dx.doi.org/10.1097/MBP.0b013e32835d12f6

Rulli, A. (2008), 'Tudengiaastad 1930-1933' [Student years 1930-1933], in A. Velliste (ed.) Ants Rulli - kirurgia professor, Tartu: Ecoprint, pp. 9-62.

(2008), 'Óppejôna Tartu Riiklikus Ülikoolis' [As a lecturer at the Tartu State University], in A. Velliste (ed.) Ants Rulli - kirurgia professor, Tartu: Ecoprint, pp. 63-157.

Tiitso, M. (1935), 'Vergleichende Untersuchungen über die Geschwindigkeitskurve der menschlichen Atmung bei Ruhe und Körperarbeit,' Arbeitsphysiologie, vol. 9, pp. 16-26. http://dx.doi.org/10.1007/bf02010005

Tiitso, M. \& Pehap, A. (1935), 'Über den Einfluss der Körperarbeit auf die Pulsfreguenz,' Arbeitsphysiologie, vol. 9, pp. 51-61.

Vasar, E.; Kingisepp, P-H.: Vaasa, I-O.; Lang, A.; Soosaar, A. \& Raamat, R. (2007), 'Füsioloogia instituut' [The Institute of Physiology], in K. Kalling (ed.) Tartu Ülikooli Arstiteaduskond 1982-2007 [The Faculty of Medicine of the University of Tartu 1982-2007], Tartu: Tartu Ülikooli Kirjastus, pp. 100-115.

Viru, A-M. (2001), 'Professor Käer-Kingisepa panus südametegevuse ja hingamise uurimisse ning spordifüsioloogia kujunemisse Eestis' [The contribution of professor Käer-Kingsepp into research of heart activity and respiration, and the development of sports physiology in Estonia], in P-H. Kingisepp Elise Käer-Kingisepp 100, Tartu: AS Atlex, pp. 43-55.

(2006), Eluhelgus ja ajavarjud [Glow of life and shadows of time], Tartu: Ilmamaa.

Leili Kriis helped to establish and develop the collections of the University of Tartu Museum from the creation of the museum in 1979 until 2015. She has published researches on the history of science and medicine, primarily in connection to the legacy of the University of Tartu. 